faulting of a pile of angular recumbent folds. In the area there is sufficient evidence based on sedimentary structures to indicate that the northerly dipping beds are inverted. Away from the granite the folds are recumbent. The bedding-plane guided faults are similar in all respects, except exposure, to the Tintagel thrusts, and, along the Dartmoor boundary just as at Tintagel, northerly translations are thought to be predominant.

Department of Geology,

W. R. Dearman.

KING'S COLLEGE, NEWCASTLE-UPON-TYNE, 1.

11th July, 1961.

\title{
REFERENCES
}

AshwIN, D. P., 1958. The Coastal Outcrop of the Culm Measures of SouthWest England. Abstracts, South-West England Conference, $R$. geol. Soc, Cornwall, 2-3.

Batstone, A. E., 1959. The Structure and Tectonic History of TintagelDavidstow Area. Trans. R. geol. Soc. Cornwall, 19, 17-32.

Dearman, W. R., and N. E. ButCher, 1959. The Geology of the Devonian and Carboniferous Rocks of the North-West Border of the Dartmoor Granite, Devonshire. Proc. Geol. Ass., Lond., 70, 51-92.

Dewey, H., 1948. British Regional Geology, South-West England (2nd ed.). Geol. Surv. and Mus., London.

House, M. R., 1959. Upper Devonian Ammonoids from North-West Dartmoor, Devonshire. Proc. Geol. Ass., Lond., 70, 315-321.

Selwood, E. B., 1961. The Upper Devonian and Lower Carboniferous Stratigraphy of Boscastle and Tintagel, Cornwall. Geol. Mag., 98, 161-167.

WILson, G., 1951. The Tectonics of the Tintagel Area, North Cornwall, Quart. J. geol. Soc., Lond., 106, 393-432.

\section{FIELD RELATIONS OF ROCKS CONTAINING CO-EXISTING PYROXENES.}

SIR,--In the recent discussion in the Geological Magazine concerning co-existing pyroxenes in metamorphic rocks, which has revealed differences of opinion as to the significance of compositional tie-line position, there has been a tendency to use mineral analyses without regard either to the immediate environment of the mineral within the rock or to the field relations of the rock as a whole.

Since five of the rocks referred to variously by Muir and Tilley (1958), O'Hara (1960), and Kretz (1961) come from Scourie, our field investigations in that area (Bowes, Wright, and Park-in press) are relevant. These have shown that the pyroxenites and peridotites described as banded ultrabasic rocks in the North-West Highlands Memoir (Peach et al., 1907) are layered ultrabasic igneous intrusive rocks. They are found in many localities in the Scourie area and their prominent mineralogical banding is unrelated to, and later than, the banding of the surrounding gneisses. A series of similar intrusions has been studied in the Lewisian foreland from Loch Laxford to Loch Torridon and their distribution bears no relation to variations in metamorphic grade.

This field evidence satisfactorily explains the presence at Scourie of the large olivine-contaiing masses regarded by O'Hara (1961) as granulite facies gneisses. It invalidates any conclusions about metamorphic pyroxenes using these rocks as examples and appears to resolve the anomalous $K_{D}$ value (Kretz, op. cit.) for the pyroxenite from Scourie (Muir and Tilley, op. cit., specimen T ; O'Hara, 1960, specimen 7). In the absence of accurate published details of locality, field relations and rock type, we are unable to state with certainty that the rock from Scourie containing the anomalous analysed 
pyroxene is from one of the igneous bodies which we have mapped, but there appear to be no other rock types in the area to which the published descriptions could apply.

The geological environments of the other two anomalous rocks also seem to provide the key to their interpretation. It appears likely that the "Olivinebearing pyroxene granulite, Eilean Carrach, Ardnamurchan, Scotland" (Muir and Tilley, op. cit., specimen R) is a thermally metamorphosed xenolith from the Hypersthene Gabbro of Centre 2. Although Richey and Thomas (1930, pp. 221-2) termed these rocks basic granulites, they imply that all these xenoliths were pyroxene-bearing igneous rocks. Similarly, the geological environment of the " Metamorphosed picrite basalt, ejected block, Kilauea" (Muir and Tilley, op. cit., specimen X) is such that igneous conditions were dominant during its pre-explosive history.

It can be concluded that the geological setting of each of the three supposedly metamorphic rocks which have $K_{D}$ values characteristic of igneous rocks (Kretz, op. cit.) is such that minerals characteristic of igneous rocks will be found. In the case of the rock from Scourie the pyroxenes are unaltered igneous pyroxenes, whereas in the rocks from Ardnamurchan and Kilauea, it seems likely that the pyroxenes are relict igneous pyroxenes or igneous pyroxenes reconstituted at igneous temperatures.

\section{REFERENCES}

Bowes, D. R., A. E. Wright, and R. G. Park. Layered intrusives in the Lewisian of the North-West Highlands of Scotland. (In the press.)

KreTz, R., 1961. Co-existing pyroxenes. Geol. Mag., 98, 344-345.

MUIR, I. D. and C. E. TILleY, 1958. The compositions of co-existing pyroxenes in metamorphic assemblages. Geol. Mag., 95, 403-408.

O'HARA, M. J., 1960. Co-existing pyroxenes in metamorphic rocks. Geol. Mag., 97, 498-503.

1961. Zoned ultrabasic and basic gneiss masses in the early Lewisian metamorphic complex at Scourie, Sutherland. J. Petrol., 2, 248-276.

PeACH, B. N., et al., 1907. The geological structure of the North-West Highlands of Scotland. Mem. geol. Surv. U.K.

RicheY, J. E. and H. H. Thomas, 1930. The geology of Ardnamurchan, North-West Mull and Coll. Mem. geol. Surv. U.K.

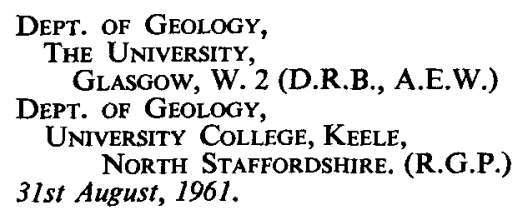

D. R. BOWES,

A. E. WRIGHT,

R. G. PARK.

\section{CO-EXISTING PYROXENES}

SIR,-In a recent issue of this magazine Dr. G. M. Brown made a revaluation of the existing data on tie-line orientation for co-existing pyroxenes in igneous assemblages. It was concluded that a precise point of intersection, at or close to $\mathrm{Wo}_{75} \mathrm{En}_{25}$ does not exist, and that, even given such a point hypothetically, its precise significance could not be easily explained. In arriving at this conclusion Dr. Brown used twelve analysed igneous pyroxene pairs. These included both orthopyroxene-augite and pigeonite-augite pairs, and were taken from six different igneous bodies.

While agreeing with Dr. Brown's general conclusions, the writer considers that as the tie-lines reflect the distribution of $\mathrm{Ca}, \mathrm{Mg}$, and $\mathrm{Fe}$ between two co-existing phases it is unreasonable to include the two different types of pairs, as orthopyroxene and pigeonite have differing crystal structures; furthermore the examples selected by Dr. Brown are from magmas cooled under differing conditions, and in which there may have been slight but 